International Research Journal of Management, IT \& Social Sciences
Available online at https://sloap.org/journals/index.php/irjmis/
Vol. 6 No. 4, July 2019, pages: 174 179
$\begin{aligned} & \text { ISSN: 2395-7492 } \\ & \text { https://doi.org/10.21744/irjmis.v6n4.675 }\end{aligned}$

\title{
Effect of Risk Preference, Professional Domination, Information, and Professional Relationship on Ethical Decision Making of Tax Consultants
}

Ida Bagus Widhi Aksiana ${ }^{a}$
I Ketut Sujana $^{b}$

Article history:

Received: 27 March 2019

Accepted: 31 May 2019

Published: 15 July 2019

\section{Keywords:}

professional dominance; information current; professional relations; risk preference; tax consultant ethical decision making;

\begin{abstract}
The purpose of this study was to determine the effect of risk preferences, professional dominance, current information, and professional relationships on tax consultant ethical decision making. This study uses a saturated sampling method with respondents being Tax Consultants Registered at the Indonesian Tax Consultant Association in the Bali Nusa Tenggara Region. Data collection methods used are questionnaires and data analysis using multiple linear regression. The results showed that risk preferences negatively affected the tax consultant's ethical decision making. Professional domination has a negative effect on tax consultant ethical decision making. Present information has a positive effect on tax consultant ethical decision making. Professional relations have a negative effect on tax consultant ethical decision making.
\end{abstract}

2395-7492@ Copyright 2019. The Author. This is an open-access article under the CC BY-SA license (https://creativecommons.org/licenses/by-sa/4.0/) All rights reserved.

\section{Author correspondence:}

Ida Bagus Widhi Aksiana,

Faculty of Economics and Business, Udayana University, Bali, Indonesia.

Email address: guswidhi@gmail.com

\section{Introduction}

Taking ethical decisions in business has many obstacles that can be grouped into organizational constraints and personal characteristics. Organizational constraints include reward systems, organizational culture, and the nature of corporate leadership while personal characteristics include misunderstanding of business, excessive commitment to the company, and ethical immaturity (Brooks \& Dunn, 2008). Trevino (1986), states that one's ethical decision making will depend on individual factors of the person making the decision, so it is deemed necessary to examine the factors that can strengthen the ethical decision making of tax consultants, especially from individual factors. One of the things that can help someone in facing an ethical dilemma is ethical orientation. Ethical orientation is an alternative pattern of one's behavior to resolve ethical dilemmas, one of which is formed by idealism (Forsyth, 1980; Higgins \& Kelleher, 2005). Idealism is related to actions that are guided by ethical and moral values. Professionals including tax consultants

${ }^{a}$ Faculty of Economics and Business, Udayana University, Denpasar, Indonesia ${ }^{\mathrm{b}}$ Faculty of Economics and Business, Udayana University, Denpasar, Indonesia 
who have high ideals should be able to maintain their independence and integrity in making a decision because they will not be easily effected by offers of economic benefits or other benefits that can drop their credibility and integrity as practitioners in the field of taxation.

Ethical decision making is not the only effect by individual factors, but also by situational factors. Trevino \& Youngblood (1990); Dewi \& Dewi (2018); as quoted by Purnamasari \& Chrismastuti (2006), state that there are two views regarding the factors that effect individual unethical actions. The first view argues that unethical actions or decision making are more effects by individual moral character, while the second view argues that unethical actions are more effect by the environment. These environmental factors can be organizational, cultural, and situational factors.

Research on the effect of situational factors on ethical decision making by tax consultants is carried out by Killian \& Doyle (2004). The study was conducted to determine the factors that effect the desire of tax consultants to aggressively avoid tax evasion. There are 15 factors tested in Killian \& Doyle (2004), and those that have a significant effect on the level of aggressive tax avoidance by tax consultants are the level of risk preference, professional dominance, information current, and professional relations. Killian \& Doyle's (2004) research shows that the factors that are proven to effect the level of aggressive tax avoidance by tax consultants are situational factors or circumstances outside the individual. Dewi \& Dwiyanti (2018), research which combines individual and situational factors in ethical decision-making results that individual factors, namely the perception of the importance of ethics and social responsibility and Machiavellian characteristics affect ethical decisions, while situational factors do not effect decision making ethical.

Of the many disclosures of tax consultant cases that facilitate tax avoidance raises the question of whether situational factors such as the tendency to take risks with the aim of getting maximum benefits, the dominance in tax practices, lack of understanding and information about tax regulations, and the existence of social interactions with clients, have a role in influencing tax consultants in making ethical decisions or conducting tax avoidance aggressively. This is what motivates researchers to conduct research on these situational factors.

The results of the research conducted by Kadous \& Magro (2001), state that although the tax consultant has a goal to provide the best results for the client, the goal will be balanced with the long-term goals of his work. Tax consultants must still consider the risks and rewards they get from all decisions taken. Furthermore, Kadous \& Magro (2001), state that tax consultants face a high risk of costs to make unethical decisions. Doyle (2004), which states that there are differences in recommendations given by tax consultants who have high and low-risk preferences. A tax consultant who is more courageous to violate tax rules and dare to accept the risks tends to provide more aggressive recommendations on tax avoidance.

Research conducted by Killian \& Doyle (2004) states that tax consultants who have a greater dominance of professionals are more likely to aggressively avoid tax evasion. Taxation practices with greater dominance have more tax management experience, so the tendency to avoid taxes aggressively is also higher. The professional dominance of the tax consultant is indicated by how many employees are in the tax department, the industry specialization in handling client taxes, and whether the manager of the consultant's practice is a tax practitioner or not. Wittmer (2010), states that organizational size has an effect on ethical decision making. It is more difficult to maintain ethical behavior in larger organizations, therefore, the leadership of the organization needs to pay attention to strategies and structures that will increase the tendency of individuals to make ethical choices. Based on Wittmer's (2010), research, it can be concluded that professional dominance has a negative effect on tax consultant ethical decision making.

\section{Literature Review}

\section{The Effect of Risk Preference on Ethical Decision Making of Tax Consultants}

Risk preference is how much risk the tax consultant is willing to take. Tax consultants must still consider the risks and rewards they get from all decisions taken. Teleology evaluates decisions as good or bad, acceptable or unacceptable in terms of the consequences of a decision. The more courageous to accept the risk, the decisions taken tend to be unethical. Conversely, the lower the level of risk that is dared to be taken, the tax consultant will be more careful in making decisions, so that the decisions taken tend to be more ethical.

According to Terry, quoted by Syamsi (2000) the definition of decision making is the choice of behavioral alternatives from two or more alternatives. According to Salusu (2003); Lisa \& Hermanto (2018); Pandey (2017), the thing that distinguishes ethical decision making from other types of decision making lies in what is called ethical principles. First, on the reasons used in producing a decision. Second, on the fact that decision-makers accept the question in question as part of their moral view, namely about good and bad. Ethical decision making is the process of

Aksiana, I. B. W., \& Sujana, I. K. (2019). Effect of Risk Preference, Professional Domination, Information, and Professional Relationship on Ethical Decision Making of Tax Consultants. International Research Journal of Management, IT and Social Sciences, 6(4), 174-179. https://doi.org/10.21744/irjmis.v6n4.675 
selecting away from several alternatives and the resulting decision does not violate legal norms and can be morally accountable.

H1: Risk preference has a negative effect on tax consultant ethical decision making.

The Effect of Professional Domination on Ethical Decision Making of Tax Consultants.

The professional dominance of tax consultants is indicated by how long it takes to practice as a tax consultant, how many employees are in the tax department, and the specialization of services in handling client taxes. Taxation practices with greater dominance have more tax management experience, so the tendency to avoid taxes aggressively is also higher. Kant's opinion in Deontology's theory that all our moral concepts come from reasons not from experience.

Based on the empirical evidence above, the hypothesis can be formulated as follows:

H2: Professional dominance has a negative effect on tax consultant ethical decision making.

\section{The Effects of Information Presentation on Ethical Decision Making of Tax Consultants}

Magro (2005), states that the acquisition of information is fundamental in making tax decisions. The information referred to here is an understanding of the latest tax rules and their application. Research conducted by Bonner $e t$ al., (1992) as quoted by Magro (2005) states that understanding information on tax rules provides a positive effect in identifying taxation issues and providing tax recommendations. Other research regarding the effect of the current information on tax consultant decision making was carried out by Killian \& Doyle (2004), who stated that the current information proved to have a significant effect on ethical decision making by tax consultants.

Tax consultants who have access to the latest tax information tend to be less aggressive in tax evasion. This is because the more consultants know the latest tax regulations, the more the ability of the resources they have so that they are able to understand all risks legally, thus the tendency to be unethical is lower.

Based on the relationship path, the following hypotheses can be formulated:

H3: Information presentation has a positive effect on tax consultant ethical decision making.

\section{The Effect of Professional Relations of Tax Consultants on Ethical Decision Making}

The professional relationship of tax consultants with clients is one of the factors that has been proven to effect the ethical decision making of tax consultants. Research conducted by Klepper \& Nagin (1989) as cited by Blanthorne, Burton, and Fisher (2005); Pattiasina et al., (2019); Prena et al., (2019); Wiguna \& Yadnyana (2019) provides results that pressure from clients will motivate tax consultants to provide aggressive tax advice. Another study conducted by Killian \& Doyle (2004) states that tax consultants who communicate more frequently with clients will be more likely to be willing to act further for the benefit of their clients.

Tax consultants in maintaining good relationships with clients tend to occur a social interaction that will increasingly establish a close relationship between tax consultants and their clients. Getting closer and intensive communication with clients leads to greater tax consultant support for clients so that tax consultants will tend to report their clients' income to a minimum in an aggressive manner.

Based on the relationship path, the following hypotheses can be formulated:

H4: The professional relationship of tax consultants has a negative effect on ethical decision making.

\section{Materials and Methods}

The study was conducted in the area of Bali Province towards members of the Indonesian Tax Consultant Association (IKPI) in the Bali Nusa Tenggara region. The population in this study were members of the Tax Consultant Registered at the Indonesian Tax Consultant Association (IKPI) in the Bali Nusa Tenggara region, totaling 130 people (the IKPI Pengda Bali Nusa Tenggara directory). The sample is part of the population taken through certain ways, clear and complete which are considered to represent the population. In this study, the technique of determining the sample used is saturated sampling or census method. This method is used if all members of the population are used as samples (Sugiyono, 2012). The data analysis tool in this study uses multiple linear regression to see the dependence of the dependent variable with one or more independent variables. 


\section{Results and Discussions}

The regression results are presented in the following Table 1.

Table 1

Multiple Regression Testing Result

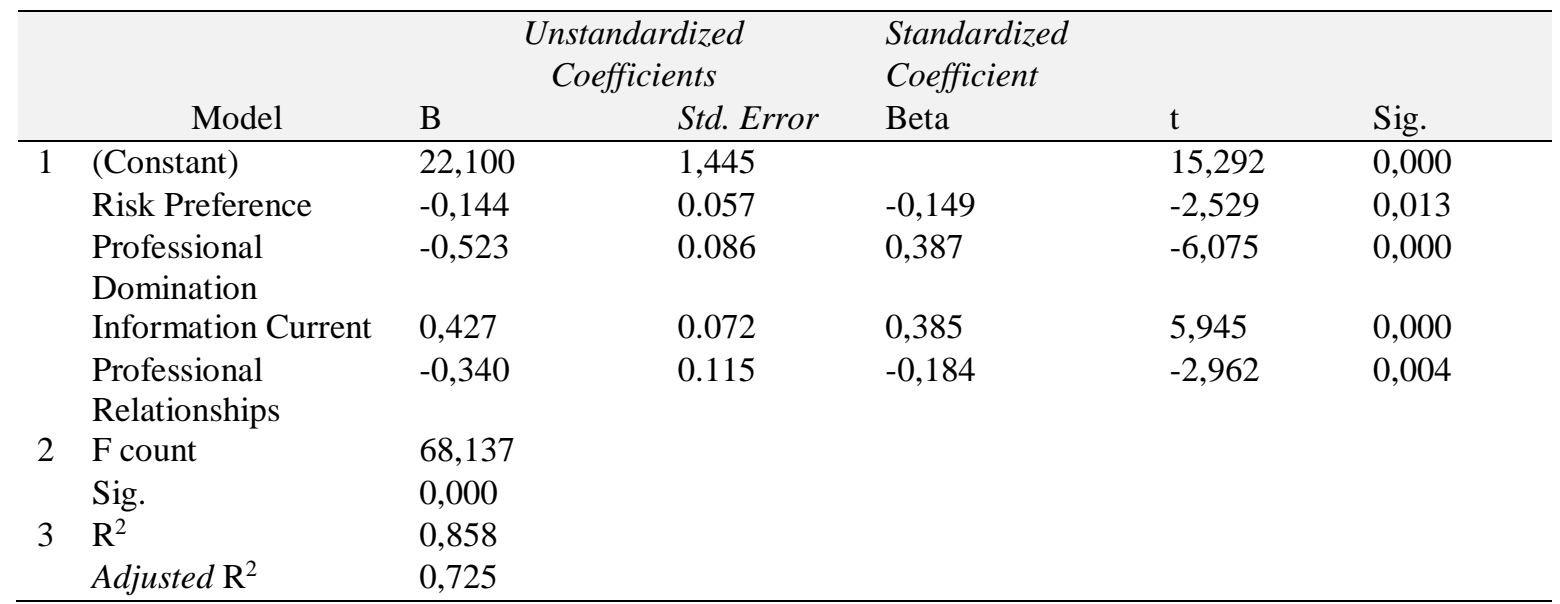

Primary Data, 2018

The first hypothesis states that risk preferences have a negative effect on tax consultant ethical decision making. The results of the hypothesis test presented in Table 1 show that the beta coefficient $(\beta 1)$ is -0.144 with a significance level of 0.013 which is less than $\alpha=0.05$, which means that $\mathrm{H} 1$ is accepted. Thus the results of the hypothesis test indicate that the risk preference has a negative effect on the tax consultant's ethical decision making.

The second hypothesis states that professional dominance has a negative effect on tax consultant ethical decision making. Table 1 shows that with a significance level of 0,000 which is less than $\alpha=0.05$, and the beta coefficient value $(\beta 2)$ is $-0,523$ which means $\mathrm{H} 2$ is accepted. Thus the results of the hypothesis test indicate that professional domination has a negative effect on the tax consultant's ethical decision making.

The third hypothesis states that the current information has a positive effect on the ethical decision making of tax consultants. Based on Table 1, the beta value $(\beta 3)$ is obtained at 0.427 and the significance level of the present information variable is 0,000 which is less than $\alpha=0.05$, which means that $\mathrm{H} 3$ is accepted. This means that the current information has a positive effect on the ethical decision making of tax consultants.

The fourth hypothesis states that professional relations tax consultants have a negative effect on tax consultant ethical decision making. Based on Table 1, the beta value (B4) is obtained at -0.340 and the significance level of the tax consultant professional relationship variable is 0.004 which is less than $\alpha=0.05$, which means that H4 is accepted. This means that the professional relationship of the tax consultant negatively affects the ethical decision making of tax consultants.

The small value of $\mathrm{R}^{2}$ means that the ability of independent variables to explain variations in the dependent variable is very limited. A value close to one means that the independent variables provide almost all the information needed to predict variations in the dependent variable. The indicator used in this study is adjusted $\mathrm{R}^{2}$. Based on Table 1, it can be seen that the coefficient of determination of adjusted $\mathrm{R}^{2}$ is 0.725 . This means that the magnitude of the effect of risk preferences, professional domination, current information, and professional relations of tax consultants with clients on tax consultant ethical decision making is $72.5 \%$, while the remaining $27.5 \%$ is effect by other variables outside the research.

Based on Table 1 it can be seen that the $F$ test produces a calculated $F$ value of 68.137 with a significance of 0.000 where the value is smaller $\alpha=0.05, \mathrm{H} 1$ is accepted and $\mathrm{H} 0$ is rejected. This means that there is an effect between risk preferences, professional domination, current information and professional relations of tax consultants with clients towards the tax consultant's ethical decision-making variables.

Aksiana, I. B. W., \& Sujana, I. K. (2019). Effect of Risk Preference, Professional Domination, Information, and Professional Relationship on Ethical Decision Making of Tax Consultants. International Research Journal of Management, IT and Social Sciences, 6(4), 174-179. https://doi.org/10.21744/irjmis.v6n4.675 


\section{Conclusion}

The Indonesian Tax Consultant Association (IKPI) has branches in several regions in Indonesia, and due to distance and time constraints in this study only uses the population of the Indonesian Nusa Tenggara Tax Consultant Association, so this study has limitations on conclusions based solely on the perception of consultant tax only in Bali and Nusa Tenggara. Future research is expected to expand the research population that is not limited to tax consultants in the Bali Nusa Tenggara region.

The determination coefficient value of adjusted $\mathrm{R}^{2}$ in the study results is 0.725 , this indicates that 72.5 percent of ethical decisions are effect by risk preference variables, professional dominance, current information, and professional relationships, while the remaining 27.5 percent are effect by other variables not discussed in the study this. This is an opportunity for further researchers to develop research related to the factors that effect the ethical decision making of tax consultants.

Conflict of interest statement and funding sources

The authors declared that they have no competing interest.

Statement of authorship

The authors have a responsibility for the conception and design of the study. The authors have approved the final article.

\section{Acknowledgments}

The authors would like to thank the Editor of IRJMIS for their valuable time, support, and advice in completing the current study. 


\section{References}

Bonner, F., \& Du Gay, P. (1992). Representing the enterprising self: thirtysomething and contemporary consumer culture. Theory, Culture \& Society, 9(2), 67-92. https://doi.org/10.1177\%2F026327692009002004

Dewi, I. G. A. A. P., \& Dewi, P. P. (2018). Big Five Personality, Ethical Sensitivity, and Performance of Auditors. International Research Journal of Management, IT and Social Sciences, 5(2), 195-209.

Dewi, P. P., \& Dwiyanti, K. T. (2018). Professional commitment, self-efficacy and ethical decision auditor. International Research Journal of Management, IT and Social Sciences, 5(6), 93-104. https://doi.org/10.21744/irjmis.v5n6.379

Doyle, E., Hughes, J. F., \& Summers, B. (2013). An empirical analysis of the ethical reasoning of tax practitioners. Journal of Business Ethics, 114(2), 325-339. https://doi.org/10.1007/s10551-012-1347-X

Doyle, M. C. (2004). U.S. Patent No. 6,745,998. Washington, DC: U.S. Patent and Trademark Office.

El-Werfelli, M., Dunn, R., Redfern, M., \& Brooks, J. (2008, September). Analysis of the national 8th November 2003 Libyan blackout. In 2008 43rd International Universities Power Engineering Conference (pp. 1-5). IEEE. https://doi.org/10.1109/UPEC.2008.4651469

Fisher, R. W. (2005). Globalization and monetary policy (No. 118). Federal Reserve Bank of Dallas.

Forsyth, D. R. (1980). A taxonomy of ethical ideologies. Journal of Personality and Social psychology, $39(1), 175$.

Kadous, K., \& Magro, A. M. (2001). The effects of exposure to practice risk on tax professionals' judgements and recommendations. Contemporary Accounting Research, 18(3), 451-475. https://doi.org/10.1506/TF76-653LR36N-13YP

Killian, S., \& Doyle, E. (2004). Tax aggression among tax professionals: the case of South Africa. Journal of Accounting, Ethics and Public Policy, 4(3).

Klepper, S., \& Nagin, D. (1989). The anatomy of tax evasion. JL Econ. \& Org., 5, 1.

Lisa, O., \& Hermanto, B. (2018). The effect of tax amnesty and taxpayer awareness to taxpayer compliance with financial condition as intervening variable. International Research Journal of Management, IT and Social Sciences, 5(2), 227-236.

Magro, J. R., Loyer, B. A., \& Mehta, P. M. (2005). U.S. Patent No. 6,889,334. Washington, DC: U.S. Patent and Trademark Office.

O’Higgins, E., \& Kelleher, B. (2005). Comparative perspectives on the ethical orientations of human resources, marketing and finance functional managers. Journal of Business Ethics, 56(3), 275-288. https://doi.org/10.1007/s10551-004-3898-y

Pandey, M. (2017). Impact of goods and service tax (GST) on Indian tax structure. International Research Journal of Management, IT and Social Sciences, 4(3), 22-33.

Pattiasina, V., Tammubua, M. H., Numberi, A., Patiran, A., \& Temalagi, S. (2019). Capital Intensity and tax avoidance. International Journal of Social Sciences and Humanities, 3(1), 58-71. https://doi.org/10.29332/ijssh.v3n1.250

Prena, G. D., Kustina, K. T., Dewi, I. G. A. A. O., Putra, I. G. C., \& Krisnanda, R. A. (2019). Tax sanctions, tax amnesty program, and tax obligation placement towards compliance report on corporate taxpayers. International Journal of Social Sciences and Humanities, 3(1), 26-35. https://doi.org/10.29332/ijssh.v3n1.249

Purnamasari, V., \& Chrismastuti, A. A. (2006). Dampak reinforcement contingency terhadap hubungan sifat machiavellian dan perkembangan moral. Simposium Nasional Akuntansi, 9.

Sugiyono, D. R. (2012). Statistika untuk penelitian. Bandung: CV. Alfabeta.

Syamsi, I. (2000). Dasar Kebijakan Keuangan Negara.

Trevino, L. K. (1986). Ethical decision making in organizations: A person-situation interactionist model. Academy of management Review, 11(3), 601-617.

Trevino, L. K., \& Youngblood, S. A. (1990). Bad apples in bad barrels: A causal analysis of ethical decision-making behavior. Journal of Applied psychology, 75(4), 378.

Wiguna, I. P. I., \& Yadnyana, K. (2019). The role of working experience moderating the effect of emotional intelligence, intellectual intelligence, and spiritual intelligence on the ethical decision of tax consultants in Bali area. International Research Journal of Management, IT and Social Sciences, 6(3), 18-28. https://doi.org/10.21744/irjmis.v6n3.624

Wittmer, D. P. (2010). Behavioral ethics in business organizations: What the research teachs us. Good business: Exercising effective and ethical leadership, 58-69.

Aksiana, I. B. W., \& Sujana, I. K. (2019). Effect of Risk Preference, Professional Domination, Information, and Professional Relationship on Ethical Decision Making of Tax Consultants. International Research Journal of Management, IT and Social Sciences, 6(4), 174-179. https://doi.org/10.21744/irjmis.v6n4.675 